\title{
Glufosinate Rate and Timing for Control of Glyphosate-Resistant Rhizomatous Johnsongrass (Sorghum halepense) in Glufosinate-Resistant Soybean
}

\author{
Randall L. Landry, Daniel O. Stephenson IV, and Brandi C. Woolam \\ Dean Lee Research and Extension Center, LSU AgCenter, Alexandria, LA 71302, USA \\ Correspondence should be addressed to Daniel O. Stephenson IV; dstephenson@agcenter.lsu.edu
}

Received 18 November 2015; Accepted 31 January 2016

Academic Editor: Patrick J. Tranel

Copyright ( 2016 Randall L. Landry et al. This is an open access article distributed under the Creative Commons Attribution License, which permits unrestricted use, distribution, and reproduction in any medium, provided the original work is properly cited.

\begin{abstract}
Field studies were conducted over a three-year period (2011, 2012, and 2013) in Louisiana to evaluate the effect of glufosinate rate and timing on glyphosate-resistant (GR) rhizomatous johnsongrass control in glufosinate-resistant soybean. Treatments included glufosinate $\left(0.5,0.6\right.$, or $0.7 \mathrm{~kg}$ ai ha $\left.{ }^{-1}\right)$ applied alone POST1 ( $46 \mathrm{~cm}$ tall johnsongrass) and sequentially 3 (POST2) or 4 (POST3) wk after POST1 at 0.5 or $0.6 \mathrm{~kg} \mathrm{ha}^{-1}$. Glufosinate $\left(0.7 \mathrm{~kg} \mathrm{ha}^{-1}\right)$ applied POST1 controlled johnsongrass $77 \%$ at soybean harvest. Averaged across sequential application rate, delaying the sequential application from POST2 to POST3 increased control from 65 to $78 \%$ at harvest. Increasing sequential application rate from 0.5 to $0.6 \mathrm{~kg} \mathrm{ha}^{-1}$ reduced johnsongrass heights $15 \%$ at harvest. Furthermore, delaying the sequential application from POST2 to POST3 reduced GR rhizomatous johnsongrass heights to $63 \%$ of the nontreated at harvest. Soybean yields were maximized following the POST1 application of glufosinate at $0.7 \mathrm{~kg} \mathrm{ha}^{-1}\left(2670 \mathrm{~kg} \mathrm{ha}^{-1}\right)$ and by applying $0.6 \mathrm{~kg} \mathrm{ha}^{-1}$ of glufosinate sequentially $\left(2620 \mathrm{~kg} \mathrm{ha}^{-1}\right)$, regardless of sequential application timing. Maximum control and soybean yield were observed following glufosinate POST1 at $0.7 \mathrm{~kg} \mathrm{ha}^{-1}$ followed by $0.6 \mathrm{~kg} \mathrm{ha}^{-1}$ at POST3. This data indicates that glufosinate is an option for management of GR rhizomatous johnsongrass.
\end{abstract}

\section{Introduction}

Louisiana growers planted 457,000, 570,000, and 579,000 ha of soybean [Glycine max (L.) Merr.] in 2013, 2014, and 2015, respectively [1]. Weed interference in soybean can cause yield losses that range from 5 to $100 \%$, depending upon weed species and species density [2-6]. Johnsongrass infestations compete with soybean for light, moisture, and nutrients, which extends time needed for seed drying and slows mechanical harvest [7]. In addition, johnsongrass infestations in soybean can reduce yields up to $42 \%$ [7] and can serve as a host for insects and diseases [8].

Johnsongrass is native to the Mediterranean region $[9,10]$ and its range has been expanded by environmental (i.e., animals, wind, and water), human (i.e., sowing as forage), and mechanical means (i.e., harvesters, cultivators). The current range of johnsongrass is from latitude $55^{\circ} \mathrm{N}$ to latitude $45^{\circ} \mathrm{S}$ and it is found on six continents; the only continent where it is not found is Antarctica [9]. Expansion to colder climates is not expected because johnsongrass rhizomes are not tolerant of freezing temperatures [11]. Information is limited on introduction into North America; however, it is reported that johnsongrass was planted extensively as a forage in the $1830 \mathrm{~s}$ [12]. By 1975, johnsongrass was reported in 59 of the 64 parishes in Louisiana [13].

Early johnsongrass control in soybean relied on combinations of cultural and mechanical methods [14, 15]. McWhorter [16, 17] reported acceptable johnsongrass control after two successive years of soil-incorporated dinitroaniline herbicides. The acetyl coenzyme-A carboxylase(ACCase-) inhibitors, which were introduced in the 1980s, provided soybean producers with a POST option for johnsongrass control. Sequential POST applications of sethoxydim, fluazifop-P, haloxyfop, quizalofop, or clethodim provided 
70 to $90 \%$ control of johnsongrass [18]. Similarly, WintonDaniels et al. [19] reported greater johnsongrass control following sequential POST applications of fenoxaprop, fluazifop-p, haloxyfop, quizalofop, and sethoxydim than a single application.

The commercialization of glyphosate-resistant (GR) soybean in the 1990s provided producers another POST option to effectively manage many broadleaf and grass weeds [2023], including rhizomatous johnsongrass. In GR soybean, glyphosate controlled johnsongrass greater than $90 \% 50$ days after treatment (DAT) $[24,25]$. As a consequence of glyphosate's excellent activity on johnsongrass and numerous other broadleaf and grassy weeds, $92 \%$ of all GR soybean acres were treated with glyphosate in 2006 in the United States [26]. However, Green and Owen [27] reported that excessive use of a single herbicide mode of action over time could result in the selection of weed biotypes that are resistant to that herbicide. The overreliance on glyphosate for weed management leads to the development of glyphosate-resistant weeds with 32 species documented globally [28]. Furthermore, GR johnsongrass has been reported in Argentina, Arkansas, Mississippi, and Louisiana [28-31]. With continued reliance on glyphosate for weed management in GR crops, it is imperative that integrated weed management strategies are developed [32, 33], specifically for GR rhizomatous johnsongrass.

Introduction of glufosinate-resistant soybean in 1996 provided growers the opportunity to apply glufosinate POST to weeds without injury to the soybean [34]. Glufosinate interrupts essential amino acid biosynthesis by inhibiting the glutamine synthetase enzyme, which is responsible for converting glutamate and ammonia to glutamine [35]. This inhibition causes a buildup of ammonia in susceptible plants which rapidly destroys cells and tissue [36, 37]. Glufosinate provides broad-spectrum control of many grass and broadleaf weeds [38, 39]. At 14 DAT, Johnson and Norsworthy [40] observed an inverse relationship between johnsongrass height at glufosinate $\left(0.7 \mathrm{~kg} \mathrm{ha}^{-1}\right)$ application and control with 96,91 , and $78 \%$ control of 15,30 , and $45 \mathrm{~cm}$ johnsongrass, respectively. However, effective johnsongrass control has been reported with sequential applications of glufosinate or herbicide combinations with glufosinate $(80 \%$ or greater $10 \mathrm{WAE}$ ), but sequential applications were made at the same rate (e.g., $590 \mathrm{~g}_{\text {ai ha }}{ }^{-1}$ followed by (fb) $590 \mathrm{~g}_{\text {ai ha }}{ }^{-1}$ ) and timing (3 and 6 wk after emergence) [41].

Johnsongrass populations resistant to both glyphosate and ACCase-inhibitors have not been discovered in Louisiana. However, current utilization of only ACCase-inhibiting herbicides to control GR rhizomatous johnsongrass populations could potentially lead to populations with multiple resistance to glyphosate and ACCase-inhibitors. Alternative strategies need to be investigated for management of current GR rhizomatous johnsongrass populations. However, limited research is available pertaining to glufosinate rates and application timings for control of GR rhizomatous johnsongrass in glufosinate-resistant soybean. Therefore, the objective of this research was to evaluate glufosinate rates and application timings for control of GR rhizomatous johnsongrass.

\section{Materials and Methods}

Three field studies were conducted in 2011, 2012, and 2013 at Louisiana State University Agricultural Center Dean Lee Research and Extension Center near Alexandria, LA. Soil was a Coushatta silt loam (fine-silty, mixed, superactive, thermic Fluventic Eutrudepts) with a $\mathrm{pH}$ of 8.0 and $1.5 \%$ organic matter. An augmented factorial arranged in a randomized complete block replicated four times was used in all studies. Treatments include an initial application (POST1) of glufosinate POST1 (Liberty 280 SL, herbicide, Bayer CropScience LP 2 T.W. Alexander Drive Research Triangle Park, North Carolina 27709) at $0.5,0.6$, or $0.7 \mathrm{~kg} \mathrm{ai} \mathrm{ha}^{-1}$ followed by a sequential application of glufosinate at 0.5 or $0.6 \mathrm{~kg} \mathrm{ha}^{-1} 3$ (POST2) or 4 (POST3) wk after POST1, plus a nontreated control.

Soybean planting in Louisiana typically begins in earlyApril; however, johnsongrass emergence can begin in earlyMarch, reach heights of 10 to $20 \mathrm{~cm}$ by mid-April, and, oftentimes, reach 30 to $50 \mathrm{~cm}$ in height at V2 to V4 soybean (Daniel O. Stephenson IV, personal communication). Therefore, glufosinate $\left(0.5,0.6\right.$, or $\left.0.7 \mathrm{~kg} \mathrm{ha}^{-1}\right)$ was applied to $46 \mathrm{~cm}$ johnsongrass (POST1). Glufosinate was applied at POST2 or POST3 to $122 \mathrm{~cm}$ johnsongrass, but johnsongrass leaf number was greater at POST3 (5 versus 7 leaves). Corresponding soybean growth stages at the POST1 and POST2/POST3 were VC to V4 (0.6 to $20 \mathrm{~cm}$ tall) and V6 to V8 (15 to $91 \mathrm{~cm}$ tall), respectively, in all years.

Herbicides were applied with a tractor-mounted, compressed-air sprayer calibrated to deliver $187 \mathrm{~L} \mathrm{ha}^{-1}$ at $145 \mathrm{kPa}$ using Teejet 11002, flat fan nozzles (Spraying Systems Co., P.O. Box 7900, Wheaton, IL 60189). Plot size was $9 \mathrm{~m}$ long and $3.9 \mathrm{~m}$ wide with four soybean rows spaced $0.97 \mathrm{~m}$ apart. "Merschman Miami 949," "Halo 494," and "HBK 4950" glufosinate-resistant soybean were planted in 2011, 2012, and 2013, respectively. Soybean was seeded at 282,400 seeds ha $^{-1}$ in 2011 and 305,900 seeds ha ${ }^{-1}$ in 2012 and 2013. All studies were conducted using conventional-tillage methods and standard soybean production practices.

Soybean injury, johnsongrass control ( $0 \%$ no control to $100 \%$ complete control), and heights were assessed 20 and 28 DAT and at harvest. Johnsongrass heights were determined by measuring five plants per plot from the soil surface to the bend of the upper most leaf. Prior to analysis, johnsongrass heights were converted to a percentage of the nontreated control. Yield was determined by harvesting the center two rows using conventional harvesting equipment. Johnsongrass densities in the nontreated averaged 200 plants $\mathrm{m}^{-2}$ prohibiting machine harvest of these plots; thus the nontreated yields were excluded from analysis. Yield was adjusted to $13 \%$ moisture before analysis.

All data were subjected to analysis of variance using PROC GLIMMIX in SAS (release 9.3, SAS Institute, Cary, NC). Type III statistics were used to test all possible fixed effects (initial and sequential glufosinate application rates and sequential glufosinate application timing) or interactions among the fixed effects. Random effects were years and replications nested within in years [42]. Considering year a random effect permits inferences about treatments to be 
TABLE 1: Significance of the main effects of initial glufosinate application rate (POST1), sequential glufosinate application rate, and sequential glufosinate application timing (POST2 or POST3) and interactions among main effects pooled across environments 20 and $28 \mathrm{~d}$ after treatment (DAT) and at harvest for glyphosate-resistant rhizomatous johnsongrass control and height as a percent of the nontreated and soybean grain yield.

\begin{tabular}{|c|c|c|c|c|c|c|c|c|}
\hline \multirow{2}{*}{ Parameter } & \multirow{2}{*}{ Data collection } & $\mathrm{IR}^{\mathrm{a}}$ & SR & ST & $\mathrm{IT} \times \mathrm{SR}$ & $\mathrm{IT} \times \mathrm{ST}$ & $\mathrm{SR} \times \mathrm{ST}$ & $\mathrm{IT} \times \mathrm{SR} \times \mathrm{ST}$ \\
\hline & & \multicolumn{7}{|c|}{$P$ value ${ }^{\mathrm{b}}$} \\
\hline \multirow{3}{*}{ Control } & $20 \mathrm{DAT}$ & 0.0002 & 0.3073 & 0.2284 & 0.1628 & 0.0853 & 0.4139 & 0.6861 \\
\hline & $28 \mathrm{DAT}$ & 0.0541 & 0.0575 & 0.0094 & 0.2399 & 0.4606 & 0.3473 & 0.6594 \\
\hline & At harvest & 0.0107 & 0.5275 & 0.0014 & 0.2678 & 0.7232 & 0.1330 & 0.4546 \\
\hline \multirow{3}{*}{ Height } & $20 \mathrm{DAT}$ & 0.0397 & 0.4905 & 0.0041 & 0.5300 & 0.3473 & 0.1703 & 0.0931 \\
\hline & $28 \mathrm{DAT}$ & 0.2998 & 0.0358 & 0.0253 & 0.1106 & 0.3439 & 0.7247 & 0.6855 \\
\hline & At harvest & 0.4725 & 0.0042 & 0.0191 & 0.8517 & 0.6954 & 0.9213 & 0.9310 \\
\hline Soybean grain yield & & 0.0076 & 0.0346 & 0.5869 & 0.2337 & 0.2896 & 0.7770 & 0.7820 \\
\hline
\end{tabular}

${ }^{\mathrm{a}}$ IR: initial glufosinate application rate (POST1); SR: sequential glufosinate application rate; ST: sequential glufosinate application timing (POST2 or POST3).

${ }^{\mathrm{b}}$ Main effects and interactions considered significant if $P \leq 0.05$.

TABLE 2: Glyphosate-resistant rhizomatous johnsongrass control $20 \mathrm{~d}$ after treatment (DAT) and at harvest and heights as a percent of the nontreated 20 DAT and soybean yield as influenced by POST1 glufosinate application rate ${ }^{\mathrm{a}}$.

\begin{tabular}{lcccc}
\hline $\begin{array}{l}\text { Rate } \\
\mathrm{kg} \mathrm{ai} \mathrm{ha}^{-1}\end{array}$ & \multicolumn{2}{c}{ Johnsongrass control } & Johnsongrass heights & $\begin{array}{c}\text { Soybean yield } \\
\text { 20 DAT (\%) }\end{array}$ \\
\hline 0.5 & $20 \mathrm{DAT}^{\mathrm{b}}(\%)$ & At harvest (\%) & $48^{\mathrm{a}}$ & $2400^{\mathrm{b}}$ \\
0.6 & $79^{\mathrm{b}}$ & $64^{\mathrm{b}}$ & $42^{\mathrm{ab}}$ & $2600^{\mathrm{ab}}$ \\
0.7 & $83^{\mathrm{a}}$ & $74^{\mathrm{ab}}$ & $41^{\mathrm{b}}$ & $2670^{\mathrm{a}}$ \\
\hline
\end{tabular}

${ }^{\mathrm{a}}$ Data pooled over sequential glufosinate application rate of 0.5 or $0.6 \mathrm{~kg}_{\text {ai ha }}{ }^{-1}$ and POST2 or POST3 sequential glufosinate application timing.

${ }^{\mathrm{b}}$ Means followed by the same letter within each column are not significantly different based on Tukey's HSD at $P \leq 0.05$.

made over a range of environments $[42,43]$. Table 1 provides $P$ values of all main effects and interactions from analysis. Least square means were calculated and means separated $(P \leq 0.05)$ using Tukey's honest significant difference test. All data were subject to arcsine square root transformation to test for normality [44], but nontransformed means are presented.

\section{Results and Discussion}

3.1. Soybean Injury. Glufosinate applied POST (0.5 to $0.7 \mathrm{~kg} \mathrm{ha}^{-1}$ ) did not cause any injury to glufosinate-resistant soybean at any evaluation date (data not shown). Pline et al. [45] reported similar results 6 and 23 DAT. In contrast, Beyers et al. [46] observed $\leq 11 \%$ injury 2 WAT, but injury was $\leq 1 \%$ 4 WAT. Results from numerous studies conclude that there is an adequate margin of crop safety with glufosinate applied POST in glufosinate-resistant soybean.

3.2. Glyphosate-Resistant Rhizomatous Johnsongrass Control. Control 20 DAT was greater following glufosinate POST1 at $0.7 \mathrm{~kg} \mathrm{ha}^{-1}(85 \%)$ and $0.6 \mathrm{~kg} \mathrm{ha}^{-1}(83 \%)$ compared with $0.5 \mathrm{~kg} \mathrm{ha}^{-1}$ (79\%) (Table 2). Furthermore, greater GR rhizomatous johnsongrass control was observed at harvest following the POST1 application of $0.7 \mathrm{~kg} \mathrm{ha}^{-1}(77 \%)$ than $0.5 \mathrm{~kg} \mathrm{ha}^{-1}$ (64\%), while control following application of 0.5 and $0.7 \mathrm{~kg} \mathrm{ha}^{-1}$ was similar to $0.6 \mathrm{~kg} \mathrm{ha}^{-1}$ (74\%) (Table 2).
In contrast, Johnson and Norsworthy [40] observed no difference in control between $0.5,0.6$, and $0.7 \mathrm{~kg} \mathrm{ha}^{-1}$ of glufosinate when applied to $45 \mathrm{~cm}$ johnsongrass with an average of 75 and $62 \%$ control 14 and 28 DAT, respectively. The increased control observed in this research may be due to higher relative humidity prior to, at, and following glufosinate applications. Glufosinate activity on common waterhemp (Amaranthus rudis Sauer), green foxtail [Setaria viridis (L.) Beauv.], Palmer amaranth (Amaranthus palmeri S. Wats.), redroot pigweed (Amaranthus retroflexus L.), and wild oat (Avena fatua L.) was greater following application when relative humidity was $90 \%$ or greater [47-49] with the relative humidity within $12 \mathrm{~h}$ of glufosinate application having the greatest effect on activity [49]. Maximum daily relative humidity following all POST applications was 92 to $94 \%$ one day prior, day of, and after application in each year (data not shown). Therefore, high relative humidity may be the reason for greater johnsongrass control observed in this study compared with that of Johnson and Norsworthy [40]. Others [25, 40, 50] also observed an increase in johnsongrass control following increased rates of glufosinate.

Although no difference in johnsongrass control was observed 20 DAT between POST2 and POST3 $(P=0.2284)$, delaying the sequential application from POST2 to POST3 increased johnsongrass control 7 and 13\% 28 DAT and at harvest, respectively (Table 3 ). This observation may be due to increased johnsongrass leaf number (5 leaves versus 7 leaves) providing greater interception of glufosinate when applied 
TABLE 3: Glyphosate-resistant rhizomatous johnsongrass control $28 \mathrm{~d}$ after treatment (DAT) and at harvest and heights as a percent of the nontreated 20 and 28 DAT and at harvest as influenced by POST2 or POST3 sequential glufosinate application timing ${ }^{\mathrm{a}}$.

\begin{tabular}{lccccc}
\hline \multirow{2}{*}{ Timing } & \multicolumn{2}{c}{ Johnsongrass control } & \multicolumn{2}{c}{ Johnsongrass heights } \\
& $28 \mathrm{DAT}^{\mathrm{b}}(\%)$ & At harvest $(\%)$ & 20 DAT $(\%)$ & 28 DAT (\%) & $49^{\mathrm{a}}$ \\
\hline POST2 & $76^{\mathrm{b}}$ & $65^{\mathrm{b}}$ & $47^{\mathrm{a}}$ & $76^{\mathrm{a}}$ \\
POST3 & $83^{\mathrm{a}}$ & $78^{\mathrm{a}}$ & $40^{\mathrm{b}}$ & $36^{\mathrm{b}}$ & $63^{\mathrm{b}}$ \\
\hline
\end{tabular}

${ }^{\mathrm{a}}$ Data pooled over POST1 glufosinate application rate of $0.5,0.6$, or $0.7 \mathrm{~kg} \mathrm{ai} \mathrm{ha}^{-1}$ and POST2 and POST3 sequential glufosinate application rate of 0.5 or $0.6 \mathrm{~kg}$ ai ha ${ }^{-1}$.

${ }^{\mathrm{b}}$ Means followed by the same letter within each column are not significantly different based on Tukey's HSD at $P \leq 0.05$.

TABLE 4: Glyphosate-resistant rhizomatous johnsongrass heights as a percent of the nontreated $28 \mathrm{~d}$ after treatment (DAT) and at harvest and soybean yield as influenced by POST2 and POST3 sequential glufosinate application rate.

\begin{tabular}{|c|c|c|c|}
\hline \multirow{2}{*}{$\begin{array}{l}\text { Rate } \\
\text { kg ai ha }^{-1}\end{array}$} & \multicolumn{2}{|c|}{ Johnsongrass heights } & \multirow{2}{*}{$\begin{array}{c}\text { Soybean yield } \\
\mathrm{kg} \mathrm{ha}^{-1}\end{array}$} \\
\hline & 28 DAT (\%) & At harvest (\%) & \\
\hline 0.5 & $48^{\mathrm{a}}$ & $77^{\mathrm{a}}$ & $2490^{\mathrm{b}}$ \\
\hline 0.6 & $37^{\mathrm{b}}$ & $62^{\mathrm{b}}$ & $2620^{\mathrm{a}}$ \\
\hline
\end{tabular}

${ }^{a}$ Data pooled over POST1 glufosinate application rate of $0.5,0.6$, or $0.7 \mathrm{~kg} \mathrm{aiha}^{-1}$ and POST2 and POST3 sequential glufosinate application timing.

${ }^{\mathrm{b}}$ Means followed by the same letter within each column are not significantly different based on Tukey's HSD at $P \leq 0.05$.

POST3. Johnson et al. [41], Wiesbrook et al. [50], and Prostko et al. [51] suggested that sequential applications of herbicides are more effective at controlling weeds.

3.3. Glyphosate-Resistant Rhizomatous Johnsongrass Heights. At 20 DAT, glufosinate applied at $0.5,0.6$, and $0.7 \mathrm{~kg} \mathrm{ha}^{-1}$ POST1 reduced johnsongrass heights 48,42 , and $41 \%$ of the nontreated control, respectively, with differences between 0.5 and $0.7 \mathrm{~kg} \mathrm{ha}^{-1}$ (Table 2), but these differences were not observed 28 DAT $(P=0.2998)$ or at harvest $(P=0.4725)$. Conversely, the sequential glufosinate application rate did not influence GR rhizomatous johnsongrass heights as a percent of the nontreated $20 \mathrm{DAT}(P=0.4905)$, but increasing the sequential glufosinate application rate from 0.5 to $0.6 \mathrm{~kg} \mathrm{ha}^{-1}$ decreased GR rhizomatous johnsongrass heights 11 and 15\% 28 DAT and at harvest, respectively (Table 4). Additionally, delaying the sequential glufosinate application timing from POST2 to POST3 decreased GR rhizomatous johnsongrass heights as a percent of the nontreated 7 to $13 \%$ at all evaluation dates (Table 3). Johnson and Norsworthy [40] reported johnsongrass stand reductions following applications of glufosinate ( 65 to $73 \%$ ), but no differences were detected between rates $28 \mathrm{DAT}$.

3.4. Soybean Yield. Soybean yields were 2400, 2600, and $2670 \mathrm{~kg} \mathrm{ha}^{-1}$ following POST1 at $0.5,0.6$, and $0.7 \mathrm{~kg} \mathrm{ha}^{-1}$, respectively, but only yields following the 0.5 and $0.7 \mathrm{~kg} \mathrm{ha}^{-1}$ rates differed (Table 2). Similarly, increasing the sequential glufosinate application rate from 0.5 to $0.6 \mathrm{~kg} \mathrm{ha}^{-1}$ increased soybean yield $130 \mathrm{~kg} \mathrm{ha}^{-1}$ (Table 4). No difference was observed between sequential glufosinate application timings
$(P=0.5869)$ with soybean yielding 2440 and $2550 \mathrm{~kg} \mathrm{ha}^{-1}$ following POST2 and POST3, respectively (data not shown). Conversely, Johnson et al. [41] observed no differences in glufosinate-resistant soybean yield following herbicide programs for johnsongrass control (2,690 to 3,160 $\mathrm{kg} \mathrm{ha}^{-1}$ ); however, differences might have been observed if their studies had not been sprayed with clethodim 10 WAE.

\section{Discussion}

The purpose of these studies was to evaluate glufosinate application rates and timings for control of GR rhizomatous johnsongrass. These data indicate that applying glufosinate POST1 at $0.7 \mathrm{~kg} \mathrm{ha}^{-1}$ followed by a sequential application of $0.6 \mathrm{~kg} \mathrm{ha}^{-1}$ POST3 provided the greatest control and reduction in GR rhizomatous johnsongrass height throughout the season. Additionally, yields were maximized following $0.7 \mathrm{~kg} \mathrm{ha}^{-1}$ of glufosinate POST1 followed by the $0.6 \mathrm{~kg} \mathrm{ha}^{-1}$, but no differences were observed between POST2 and POST3. Although data show that glufosinate will control GR rhizomatous johnsongrass, utilization of only one herbicidal site of action (glufosinate in this case) for weed management is not a proper implementation of a herbicide resistance management program. Therefore, we suggest the use of glufosinate as part of a herbicide resistance management program that contains ACCase-inhibiting herbicides, such as clethodim or quizalofop p-ethyl, and acetolactate synthase(ALS-) inhibiting herbicides, such as imazethapyr or chlorimuron, as POST applications in glufosinate-resistant soybean to manage GR rhizomatous johnsongrass and, potentially, other problematic weeds.

\section{Conflict of Interests}

The authors declare that there is no conflict of interests regarding the publication of this paper.

\section{Acknowledgments}

The authors would like to thank the Louisiana Soybean and Feed Grain Research and Promotion Board for funding this research. In addition, the author thank the support staff at the Louisiana State University Agricultural Center Dean Lee Research for their help with this research. This paper was approved for publication by the Louisiana State University Agricultural Center as journal article no. 2016-263-25892. 


\section{References}

[1] USDA-NASS, “Quick Stats Lite”, October 2015, http://www .nass.usda.gov/Quick_Stats/Lite/result.php?0B4C6D6A-EAA5375E-98BF-A4E5B9CE2A2C.

[2] E.-C. Oerke, “Crop losses to pests," Journal of Agricultural Science, vol. 144, no. 1, pp. 31-43, 2006.

[3] T. E. Klingaman and L. R. Oliver, "Palmer amaranth (Amaranthus palmeri) interference in soybeans (Glycine max)," Weed Science, vol. 42, no. 4, pp. 523-527, 1994.

[4] J. L. Shurtleff and H. D. Coble, "Interference of certain broadleaf weed species in soybeans (Glycine max)," Weed Science, vol. 33, no. 5, pp. 654-657, 1985.

[5] H. D. Coble and R. L. Ritter, "Pennsylvania smartweed (Polygonum pensylvanicum) interference in soybeans (Glycine max)," Weed Science, vol. 26, no. 6, pp. 556-559, 1978.

[6] J. A. Baysinger and B. D. Sims, "Giant ragweed (Ambrosia trifida) interference in soybeans (Glycine max)," Weed Science, vol. 39, no. 3, pp. 358-362, 1991.

[7] C. G. McWhorter and E. E. Hartwig, "Competition of johnsongrass and cocklebur with six soybean varieties," Weed Science, vol. 20, no. 1, pp. 56-59, 1972.

[8] C. G. McWhorter, "History, biology, and control of johnsongrass," Reviews of Weed Science, vol. 4, pp. 85-121, 1989.

[9] L. G. Holm, D. L. Plucknett, J. V. Pancho, and J. P. Herberger, Eds., The World's Worst Weeds, Distribution and Biology, Krieger Publishing, Malabar, Fla, USA, 1991.

[10] E. R. Spencer, Ed., All About Weeds, Dover Publications, New York, NY, USA, 1974.

[11] S. I. Warwick and L. D. Black, "The biology of Canadian weeds.: 61. Sorghum halepense (L.) pers," Canadian Journal of Plant Science, vol. 63, no. 4, pp. 997-1014, 1983.

[12] C. G. McWhorter, "Anatomy of johnsongrass," Weed Science, vol. 19, no. 4, pp. 385-393, 1971.

[13] C. M. Allen, Ed., Grasses of Louisiana, University of Southwest Louisiana Publishing, Lafayette, La, USA, 1975.

[14] J. D. Nalewaja, "Cultural practices for weed resistance management," Weed Technology, vol. 13, no. 3, pp. 643-646, 1999.

[15] W. P. Anderson, Ed., Weed Science Principles and Application, West Publishing Company, St. Paul, Minn, USA, 1996.

[16] C. G. McWhorter, "Johnsongrass control in soybeans with trifluralin and nitralin," Weed Science, vol. 22, no. 2, pp. 111-115, 1974.

[17] C. G. McWhorter, "Johnsongrass control in soybeans with soilincorporated dinitroaniline herbicides," Weed Science, vol. 25, no. 3, pp. 264-267, 1977.

[18] W. G. Johnson and R. E. Frans, "Johnsongrass (Sorghum halepense) control in soybeans (Glycine max) with postemergence herbicides," Weed Technology, vol. 5, no. 1, pp. 87-91, 1991.

[19] K. Winton-Daniels, R. Frans, and M. McClelland, "Herbicide systems for johnsongrass (Sorghum halepense) control in soybeans (Glycine max)," Weed Technology, vol. 4, no. 1, pp. 115-122, 1990.

[20] C. M. Ateh and R. G. Harvey, "Annual weed control by glyphosate in glyphosate-resistant soybean (Glycine max)," Weed Technology, vol. 13, no. 2, pp. 394-398, 1999.

[21] X. Delannay, T. T. Bauman, D. H. Beighley et al., "Yield evaluation of a glyphosate-tolerant soybean line after treatment with glyphosate," Crop Science, vol. 35, no. 5, pp. 1461-1467, 1995.
[22] K. A. Nelson and K. A. Renner, "Weed management in wideand narrow- row glyphosate resistant soybean," Journal of Production Agriculture, vol. 12, no. 3, pp. 460-465, 2013.

[23] E. P. Webster, K. J. Bryant, and L. D. Earnest, "Weed control and economics in nontransgenic and glyphosate-resistant soybean (Glycine max)," Weed Technology, vol. 13, no. 3, pp. 586-593, 1999.

[24] A. S. Culpepper, A. C. York, R. B. Batts, and K. M. Jennings, "Weed management in glufosinate- and glyphosate-resistant soybean (Glycine max)," Weed Technology, vol. 14, no. 1, pp. 77$88,2000$.

[25] J. L. Griffin, D. K. Miller, and M. E. Salassi, "Johnsongrass (Sorghum halepense) control and economics of using glyphosate-resistant soybean in fallowed sugarcane fields," Weed Technology, vol. 20, no. 4, pp. 980-985, 2006.

[26] USDA-NASS, "Agricultural Chemical Use Database," October 2015, http://www.pestmanagement.info/nass/.

[27] J. M. Green and M. D. K. Owen, "Herbicide resistant crops: utilities and limitations for herbicide resistant weed management," Journal of Agricultural and Food Chemistry, vol. 59, no. 11, pp. 5819-5829, 2011.

[28] I. Heap, "The International Survey of Herbicide Resistant Weeds," 2015, http://www.weedscience.org/.

[29] D. B. Johnson, J. K. Norsworthy, and R. C. Scott, "Distribution of herbicide-resistant johnsongrass (Sorghum halepense) in Arkansas," Weed Technology, vol. 28, no. 1, pp. 111-121, 2014.

[30] D. S. Riar, J. K. Norsworthy, D. B. Johnson, R. C. Scott, and M. Bagavathiannan, "Glyphosate resistance in a johnsongrass (Sorghum halepense) biotype from Arkansas," Weed Science, vol. 59, no. 3, pp. 299-304, 2011.

[31] M. M. Vila-Aiub, M. C. Balbi, P. E. Gundel, C. M. Ghersa, and S. B. Powles, "Evolution of glyphosate-resistant Johnsongrass (Sorghum halepense) in glyphosate-resistant soybean," Weed Science, vol. 55, no. 6, pp. 566-571, 2007.

[32] G. M. Dill, "Glyphosate-resistant crops: history, status and future," Pest Management Science, vol. 61, no. 3, pp. 219-224, 2005.

[33] S. O. Duke, "Taking stock of herbicide-resistant crops ten years after introduction," Pest Management Science, vol. 61, no. 3, pp. 211-218, 2005.

[34] E. Rasche and M. Gadsby, "Glufosinate ammonium tolerant crops-international commercial developments and experiences," in Proceedings of the Brighton Crop Protection Conference-Weeds, Brighton, UK, November 1997.

[35] S. O. Duke, "Overview of herbicide mechanisms of action," Environmental Health Perspectives, vol. 87, pp. 263-271, 1990.

[36] K. Tachibana, T. Watanabe, Y. Sekizuwa, and T. Takematsu, "Accumulation of ammonia in plants treated with bialaphos," Journal of Pesticide Science, vol. 11, no. 1, pp. 33-37, 1986.

[37] H. Sauer, A. Wild A, and W. Rühle, "The effect of phosphinothricin (glufosinate) on photosynthesis-II. The causes of inhibition of photosynthesis," Biosciences Zeitschrift für Naturforschung C, vol. 42, no. 3, pp. 270-278, 1997.

[38] J. L. Corbett, S. D. Askew, W. E. Thomas, and J. W. Wilcut, "Weed efficacy evaluations for bromoxynil, glufosinate, glyphosate, pyrithiobac, and sulfosate," Weed Technology, vol. 18, no. 2, pp. 443-453, 2004.

[39] B. E. Tharp, O. Schabenberger, and J. J. Kells, "Response of annual weed species to glufosinate and glyphosate," Weed Technology, vol. 13, no. 3, pp. 542-547, 1999. 
[40] D. B. Johnson and J. K. Norsworthy, "Johnsongrass (Sorghum halepense) management as influenced by herbicide selection and application timing," Weed Technology, vol. 28, no. 1, pp. 142150, 2014.

[41] D. B. Johnson, J. K. Norsworthy, and R. C. Scott, "Herbicide programs for controlling glyphosate-resistant johnsongrass (Sorghum halepense) in glufosinate-resistant soybean," Weed Technology, vol. 28, no. 1, pp. 10-18, 2014.

[42] D. C. Blouin, E. P. Webster, and J. A. Bond, "On the analysis of combined experiments," Weed Technology, vol. 25, no. 1, pp. 165-169, 2011.

[43] C. G. Carmer, W. E. Nyquist, and W. M. Walker, "Least significant differences in combined analyses of experiments with twoor three-factor treatment designs," Agronomy Journal, vol. 81, no. 4, pp. 655-672, 1989.

[44] W. H. Ahrens, D. J. Cox, and G. Budhwar, "Use of the arcsine and square root transformations for subjectively determined percentage data," Weed Science, vol. 38, no. 4-5, pp. 452-458, 1990.

[45] W. A. Pline, K. K. Hatzios, and E. S. Hagood, "Weed and herbicide-resistant soybean (Glycine max) response to glufosinate and glyphosate plus ammonium sulfate and pelargonic acid," Weed Technology, vol. 14, no. 4, pp. 667-674, 2000.

[46] J. T. Beyers, R. J. Smeda, and W. G. Johnson, "Weed management programs in glufosinate-resistant soybean (Glycine max)," Weed Technology, vol. 16, no. 2, pp. 267-273, 2002.

[47] D. M. Anderson, C. J. Swanton, J. C. Hall, and B. G. Mersey, “The influence of temperature and relative humidity on the efficacy of glufosinate-ammonium," Weed Research, vol. 33, no. 2, pp. 139147, 1993.

[48] E. Coetzer, K. Al-Khatib, and T. M. Loughin, "Glufosinate efficacy, absorption, and translocation in amaranth as affected by relative humidity and temperature," Weed Science, vol. 49, no. 1, pp. 8-13, 2001.

[49] R. J. L. Ramsey, G. R. Stephenson, and J. C. Hall, "Effect of relative humidity on the uptake, translocation, and efficacy of glufosinate ammonium in wild oat (Avena fatua)," Pesticide Biochemistry and Physiology, vol. 73, no. 1, pp. 1-8, 2002.

[50] M. L. Wiesbrook, W. G. Johnson, S. E. Hart, P. R. Bradley, and L. M. Wax, "Comparison of weed management systems in narrow-row, glyphosate- and glufosinate-resistant soybean (Glycine max)," Weed Technology, vol. 15, no. 1, pp. 122-128, 2001.

[51] E. P. Prostko, W. C. Johnson III, and B. G. Mullinix Jr., "Annual grass control with preplant incorporated and preemergence applications of ethalfluralin and pendimethalin in peanut (Arachis hypogaea)," Weed Technology, vol. 15, no. 1, pp. 36-41, 2001. 


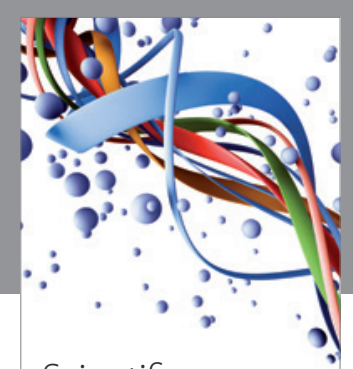

Scientifica
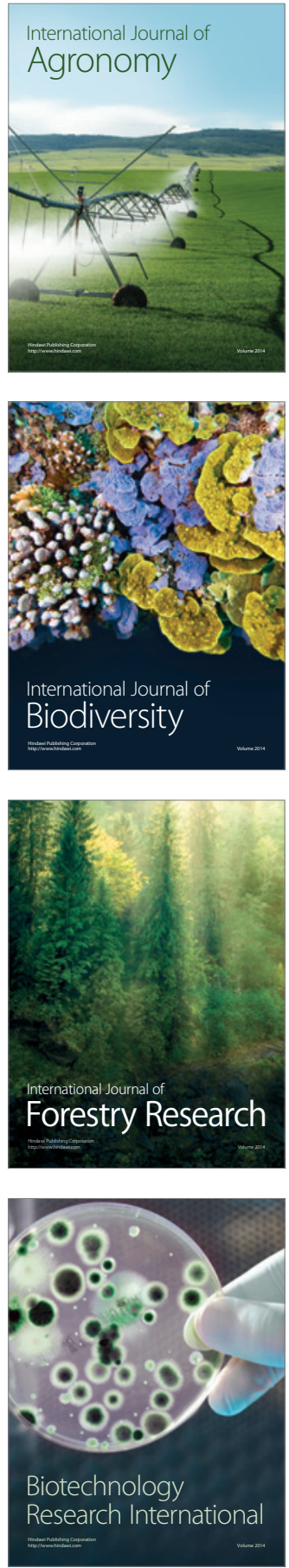
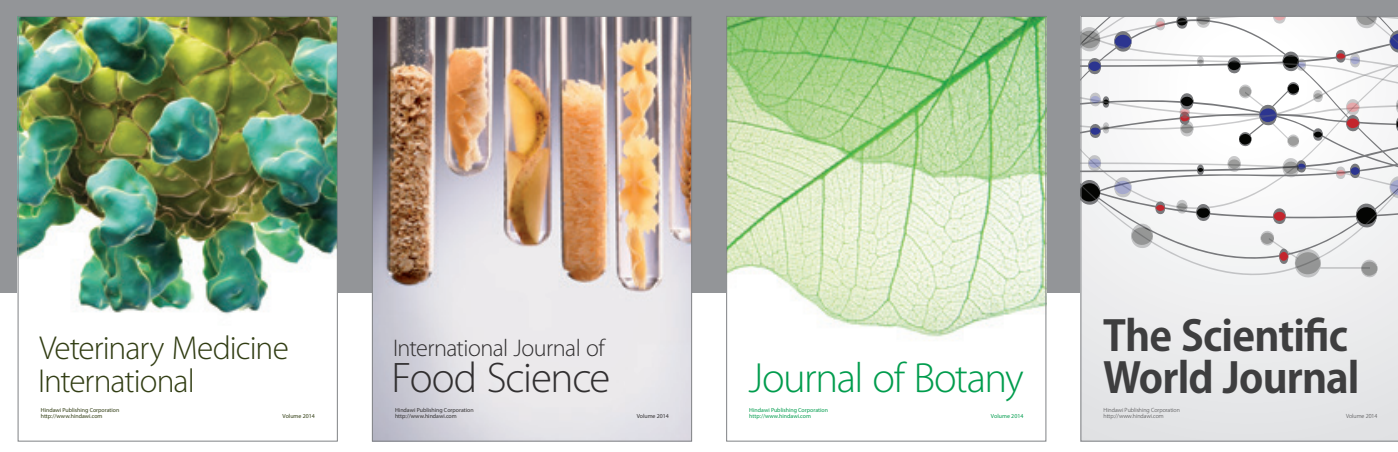

The Scientific

\section{World Journal}

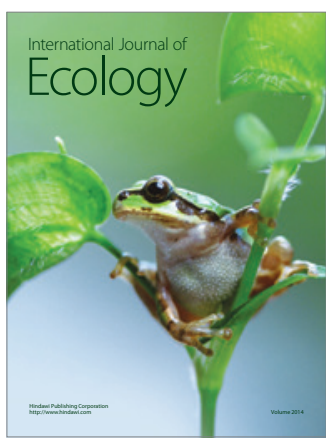

\section{Hindawi}

Submit your manuscripts at

http://www.hindawi.com
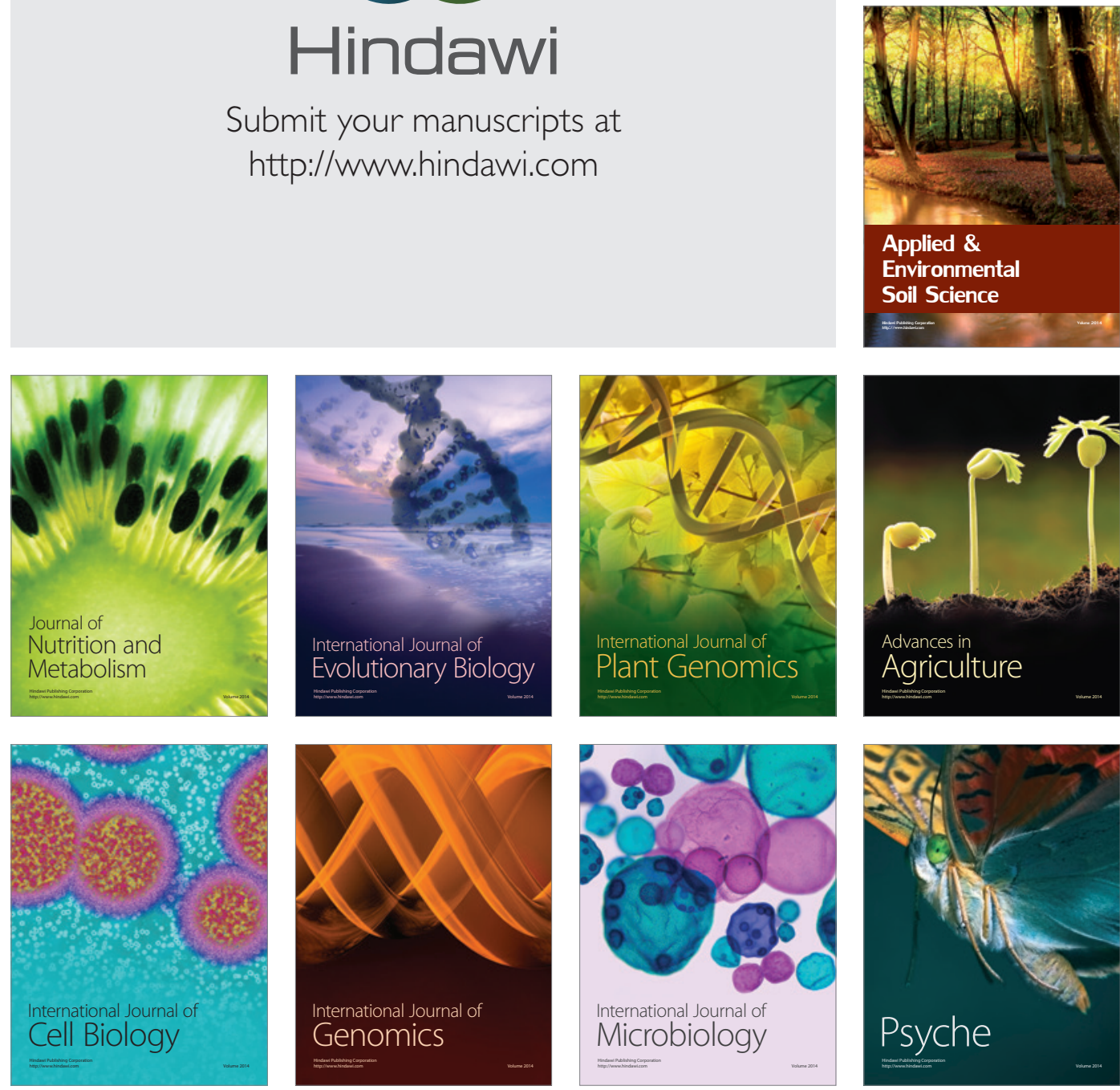
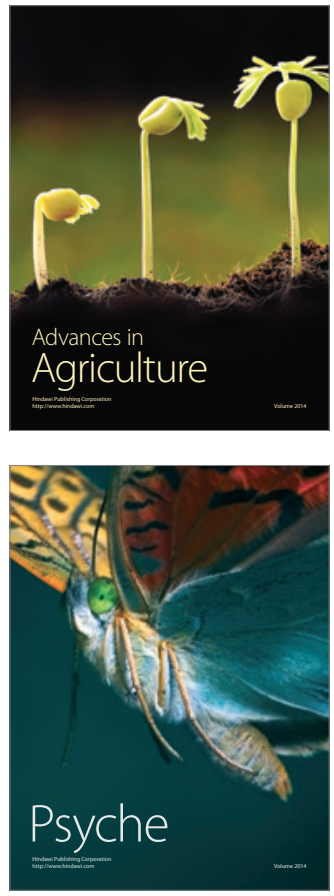